\title{
Diametric calix[6]arene-based phosphine gold(I) cavitands
}

\author{
Gabriele Giovanardi, Andrea Secchi ${ }^{*}$, Arturo Arduini and Gianpiero Cera ${ }^{\star}$
}

\author{
Letter \\ Address: \\ Dipartimento di Scienze Chimiche, della Vita e della Sostenibilità \\ Ambientale, Università di Parma, Parco Area delle Scienze 17/A, \\ 43124 Parma, Italy \\ Email: \\ Andrea Secchi ${ }^{*}$ - andrea.secchi@unipr.it; Gianpiero Cera* - \\ gianpiero.cera@unipr.it \\ * Corresponding author \\ Keywords: \\ 1,2,3-alternate conformation; calix[6]arenes; gold(I) catalysis; \\ phosphines
}

Open Access

\begin{abstract}
Beilstein J. Org. Chem. 2022, 18, 190-196.
\end{abstract} https://doi.org/10.3762/bjoc.18.21

Received: 23 December 2021

Accepted: 02 February 2022

Published: 10 February 2022

This article is part of the thematic issue "Supramolecular approaches to mediate chemical reactivity".

Guest Editor: C. Gaeta

(C) 2022 Giovanardi et al.; licensee Beilstein-Institut. License and terms: see end of document.

\begin{abstract}
We report the synthesis and characterization, in low polarity solvents, of a novel class of diametric phosphine gold(I) cavitands characterized by a 1,2,3-alternate geometry. Preliminary catalytic studies were performed on a model cycloisomerization of 1,6enynes as a function of the relative orientation of the bonded gold(I) nuclei with respect to the macrocyclic cavity.
\end{abstract}

\section{Introduction}

One of the latest challenges in supramolecular chemistry is the design and development of novel macrocyclic-based entities able to influence the catalytic activities of the metal center [1-3]. In this context, phosphines represent the most exploited class of ligands in homogeneous catalysis [4]. Noteworthy, reason of their wide applicability is the possibility of controlling the steric and electronic properties by proper functionalizations, hence tuning the catalytic properties of the bonded metal. This crucial aspect prompted their application in supramolecular chemistry as well. Thus, a recent evolution of their chemistry concerns the development of novel architectures in which P(III) compounds are incorporated in cavity-shaped macrocycles [5-8]. In this scenario, calix[4]- [9-13] and resorcin[4]arene [14-17] are the most exploited cavitands due to their inherent limited flexibility and already proved their ability to control the catalytic activity of late-transition metals and particularly gold(I) catalysts [18-25]. This occurs via strong steric interactions, often outside the macrocycle (Figure 1a) [11], that affect the first coordination sphere of the metal or by creating a spatial confinement around the metal that is thus directed towards the inner cavity (Figure 1b) [26,27]. Contrarily, calix[6]arene macrocycles are less exploited in catalysis [28]. The larger macrocycle size, its conformational adaptability, and the possibility to selectively functionalize the macrocycle offered several opportunities to design synthetic receptors and prototypes of nanodevices, instead [29]. In this context, we recently devised a new family of triphosphine calix[6]arene gold(I) complexes (Figure 1c) [30]. These cavitands are able to form (pseudo)rotaxane species, by threading viologen-based guests, with a conformational control operated by the sulfonamido hydrogen-bonding donor domain [31,32]. Furthermore, their catalytic activity was demonstrated in promoting gold(I)catalyzed cycloisomerization of 1,6-enynes, with ample scope and high regioselectivity. However, preliminary studies sug- 
a)

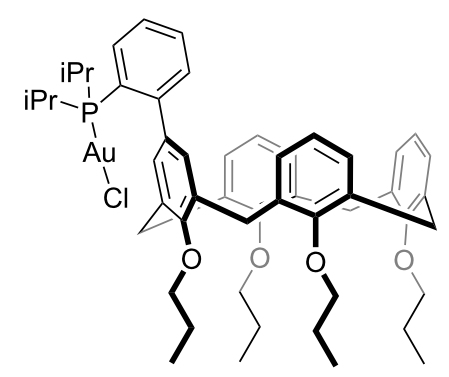

b)

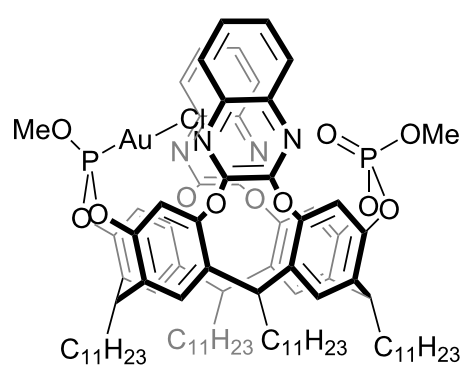

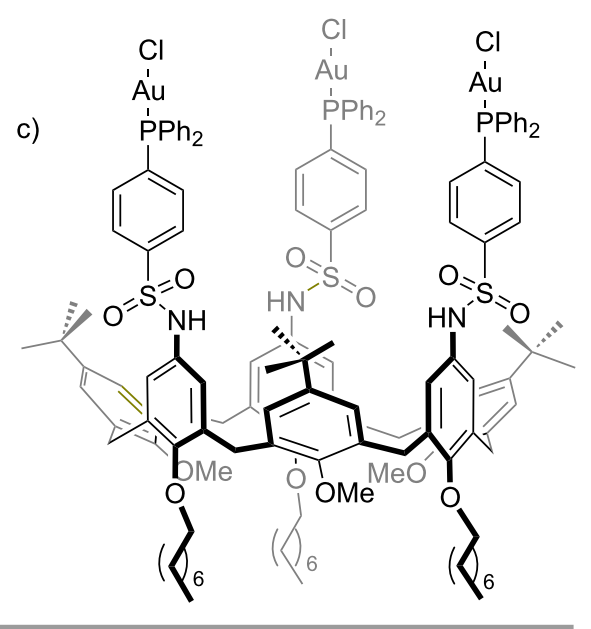

d) this work

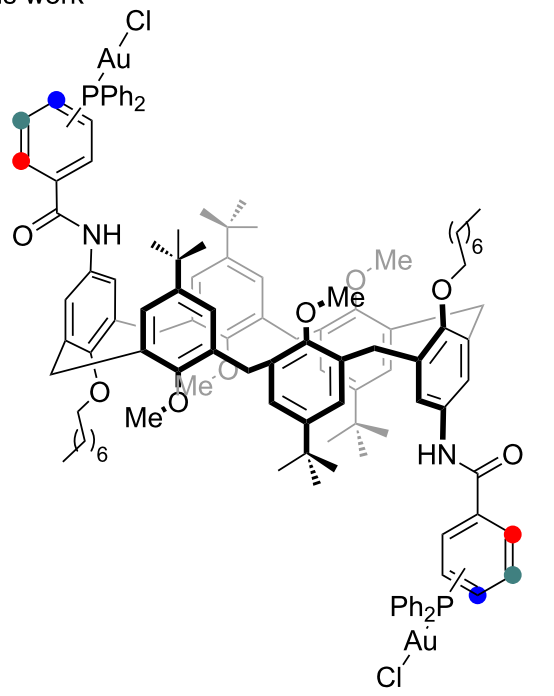
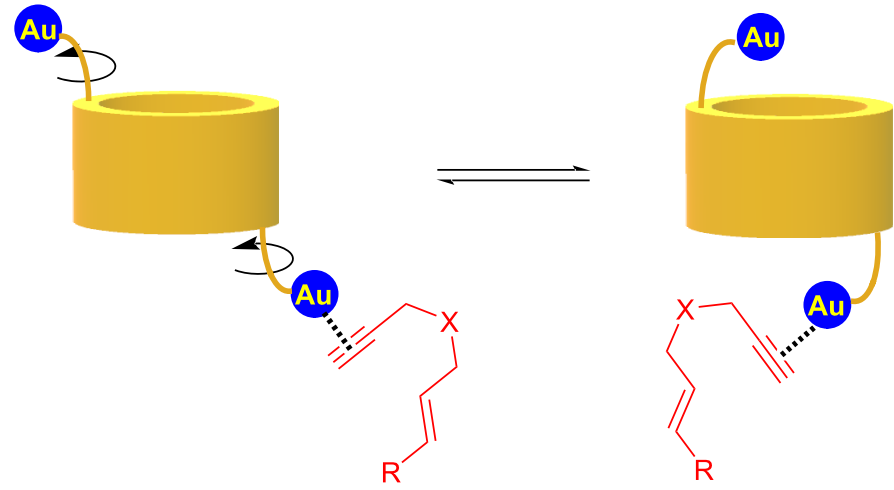

- control of the regioselectivity via cavity proximity effect

Figure 1: Selected examples of: a) calix[4]arene-; b) resorcin[4]arene-; c) calix[6]arene-gold(I) macrocyclic catalysts. d) Working hypothesis for novel calix[6]arene phosphine cavitands.

gested that the catalytic event occurs outside the macrocyclic cavity. In order to get more insights on the role of the cavity to dictate the position of the metal centers, we reasoned on the possibility to design a novel generation of diametric phosphine gold(I) cavitands exploiting a calix[6]arene scaffold characterized by a 1,2,3-alternate conformation. As working hypothesis, this geometry would segregate two catalytically active gold(I) nuclei to the opposite sides of the macrocycle, offering them the possibility to approach the cavity, thus exerting any control over the catalytic manifold (Figure 1d).

\section{Results and Discussion \\ Synthesis and characterization}

The synthesis of novel macrocyclic calix[6]arene ligands was first attempted starting from the known dioctyloxydinitro derivative DN (Scheme 1) [33]. Reduction of the nitro groups with hydrazine, in the presence of catalytic amounts of $\mathrm{Pd} / \mathrm{C}$ (10 mol \%) led to the corresponding diamino intermediate. This latter could be subsequently reacted with the desired phosphino benzoic acid derivative through a user-friendly amide coupling in the presence of $\mathrm{EDC} \cdot \mathrm{HCl}$ and catalytic amounts of DMAP in $\mathrm{CH}_{2} \mathrm{Cl}_{2}$. Under these conditions, the corresponding diphosphine intermediates A (para), B (meta), and C (ortho) were isolated in moderate yields. Finally, gold(I) catalysts could be obtained via conventional protocols using $\left(\mathrm{Me}_{2} \mathrm{~S}\right) \mathrm{AuCl}$. Notably, the organometallic macrocycles $\mathbf{A}, \mathbf{B}, \mathbf{C}(\mathrm{AuCl})_{2}$ could be isolated via column chromatography separation.

Gold(I) catalysts were subsequently fully characterized by NMR analysis and high-resolution mass spectrometry. The conformation of the catalysts, in low polarity solvents, is dominated by the 1,2,3-alternate conformation assumed by the DN 


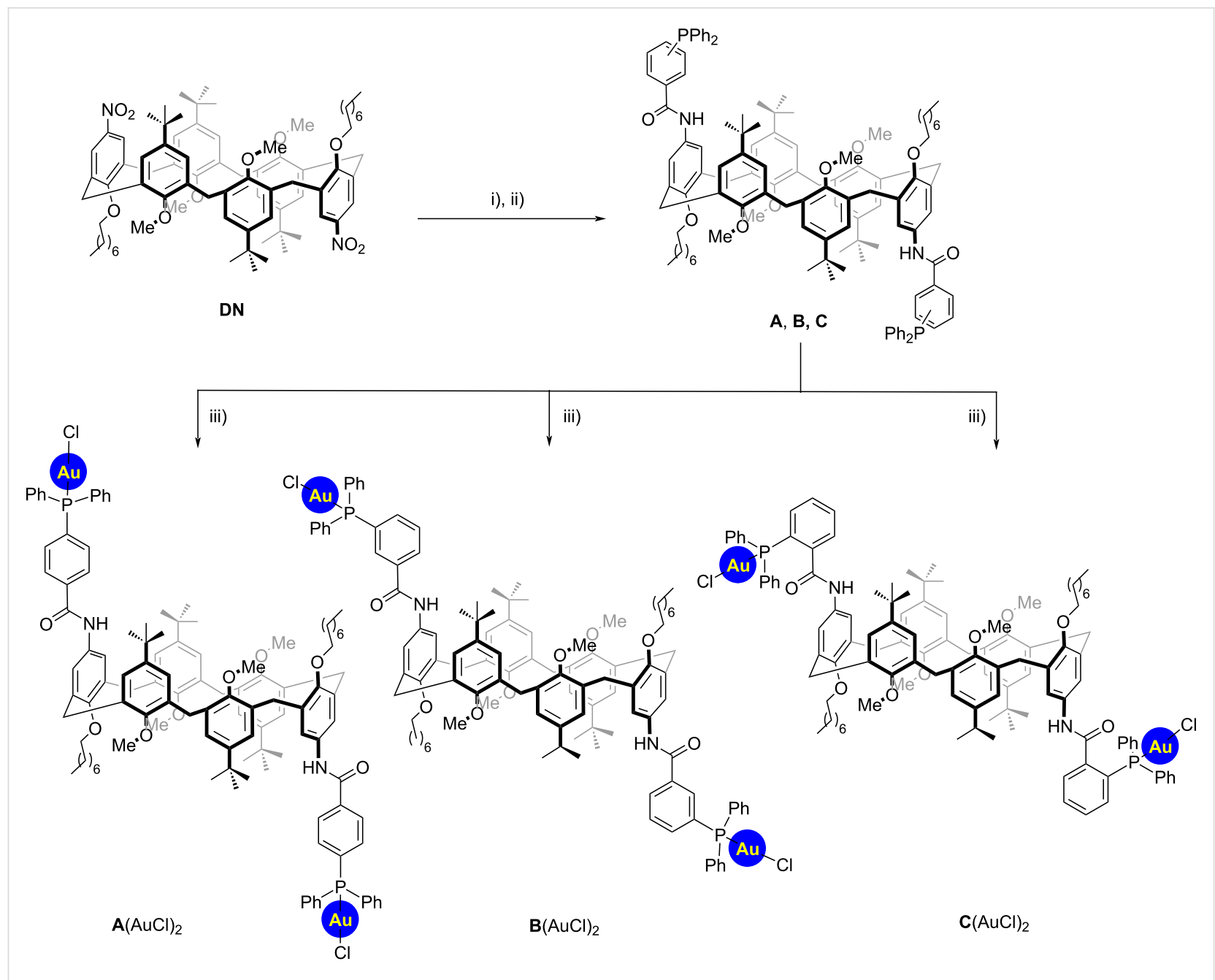

Scheme 1: i) $\mathrm{NH}_{2} \mathrm{NH}_{2} \cdot \mathrm{H}_{2} \mathrm{O}, \mathrm{Pd} / \mathrm{C}$ in EtOH, $80{ }^{\circ} \mathrm{C}$ (quant.); ii) diphenylphosphinobenzoic acid, EDC.HCl, DMAP (cat.), $\mathrm{CH}_{2} \mathrm{Cl}_{2}, 0{ }^{\circ} \mathrm{C}$ to rt [A, $60 \%$; B, $55 \%, \mathbf{C}, 53 \%)$; iii) $\left(\mathrm{Me}_{2} \mathrm{~S}\right) \mathrm{AuCl}$ in $\mathrm{CH}_{2} \mathrm{Cl}_{2}, 0{ }^{\circ} \mathrm{C}$ to rt $\left(\mathbf{A}(\mathrm{AuCl})_{2}, 93 \% ; \mathbf{B}(\mathrm{AuCl})_{2}, 74 \% ; \mathbf{C}(\mathrm{AuCl})_{2}, 69 \%\right)$.

intermediate, as previously demonstrated in our recent contributions [33,34]. Hence, the most notable features of ${ }^{1} \mathrm{H}$ NMR for $\mathbf{A}(\mathrm{AuCl})_{2}$ are represented by a pattern for the methylene bridging protons in a 1:1:1 integration ratio (Figure 2). These include: i) two doublets at 4.2 and $3.6 \mathrm{ppm}$ with a geminal coupling of ${ }^{2} J=14.2 \mathrm{~Hz}$ for the a/a' couple and ii) a singlet at $3.92 \mathrm{ppm}$ for the $\mathrm{b} / \mathrm{b}^{\prime}$ couple, typical of an anti-orientation [35]. This situation suggests a single inversion point which confers to the macrocycle a high symmetrical geometry. Finally, a single broad peak for the four methoxy groups (\$) appears at $2.96 \mathrm{ppm}$. In analogy with parental diureido and dithioureido calix[6]arenes, we were able to observe the presence of a second minor cone conformer, in a $\approx 4: 1$ ratio, highlighted by the presence of a second, single resonance for the methoxy groups (\$*) at $3.11 \mathrm{ppm}$. An analogous situation was observed for $\mathbf{B}(\mathrm{AuCl})_{2}$ and $\mathbf{C}(\mathrm{AuCl})_{2}$ as well. However, here the singlets for the $b / b$ ' couple overlap with the signals of the octyloxy chains $(\mathfrak{f})$ at 3.91 and $3.87 \mathrm{ppm}$, respectively.
The presence of these two major conformers, in slow exchange on the NMR timescale, was finally confirmed by variable temperature NMR analysis performed for $\mathbf{A}(\mathrm{AuCl})_{2}$ using tetrachloroethane- $d_{2}$ as the solvent (Figure 3).

\section{Catalytic studies}

To probe the role of the cavity and the influence of the position of the gold(I) nuclei implanted on the calix[6]arene scaffold, we carried out the synthesis of three monomeric gold catalyst analogues $\mathbf{A}^{\prime}, \mathbf{B}^{\prime}, \mathbf{C}^{\prime}(\mathrm{AuCl})$. The synthesis of these compounds was performed using the previously optimized protocol, starting from a 4-(octyloxy)aniline intermediate (Scheme 2).

Subsequently, due to the general interest in controlling the reactivity of gold(I)-catalyzed transformations by means of supramolecular macrocycles, we choose a cycloisomerization of 1,6enynes as a model reaction [36]. Substrate 1a was reacted in the presence of monomeric gold(I) catalyst $\mathbf{A}^{\prime}(\mathrm{AuCl})(2 \mathrm{~mol} \%)$, 


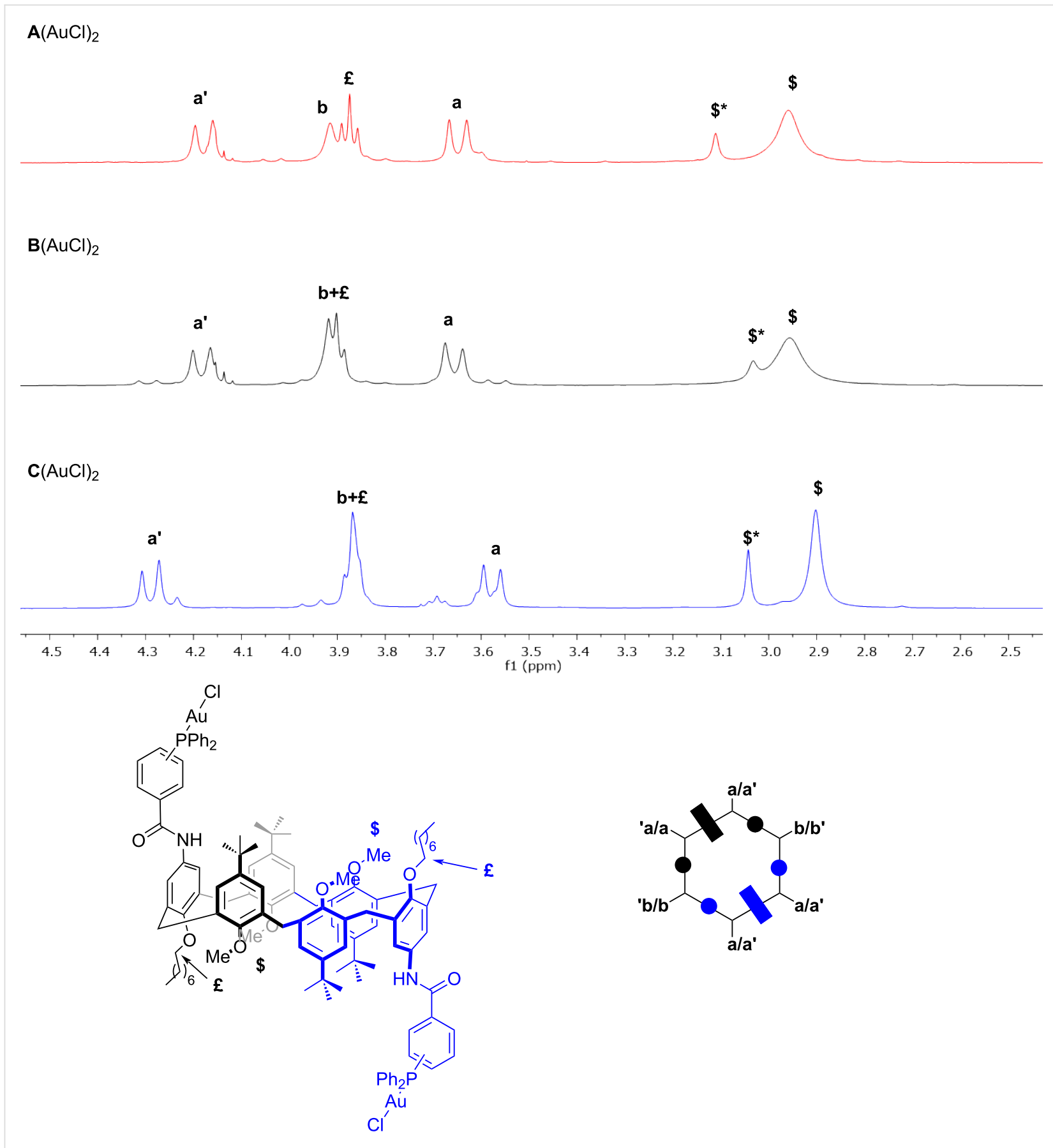

Figure 2: Stacked-plot, mid-field expanded region of the ${ }^{1} \mathrm{H}$ NMR spectrum $(400 \mathrm{MHz}, 298 \mathrm{~K})$ of $\mathbf{A}(\mathrm{AuCl})_{2}, \mathbf{B}(\mathrm{AuCl})_{2}$, and $\mathbf{C}(\mathrm{AuCl})_{2}$ in $\mathrm{CDCl}{ }_{3} . \mathrm{At}$ the bottom are schematic representations of calix[6]arene macrocycles. The rectangle identifies the phenolic ring substituted with the octyloxy chains, while the circle identifies those with methoxy groups.

using $\mathrm{AgSbF}_{6}$ as the chloride scavenger [37]. After $4 \mathrm{~h}, \mathrm{NMR}$ analysis of the crude reaction mixture revealed high conversion of the starting material with the formation of the 6-endo-dig rearranged diene $\mathbf{2 a}$ and the parental regioisomer $\mathbf{2 b}$ in a 1:1 ratio. Noteworthy, this latter is formed by an initial 5-exo-dig cyclization step (entry 1, Table 1) [38,39]. This result was compared with the one obtained using the macrocyclic analogue $\mathbf{A}(\mathrm{AuCl})_{2}$
(1 mol \%). Hence, we did not observe a significant variation in the product distribution (entry 2, Table 1).

Analogously, the reactivity in the presence of meta-substituted catalysts $\mathbf{B}^{\prime}(\mathrm{AuCl})$ and $\mathbf{B}(\mathrm{AuCl})_{2}$ was investigated. Also in this case, the reactivity and selectivity of the parental catalysts were comparable (entries 3 and 4, Table 1). Taken together, these 


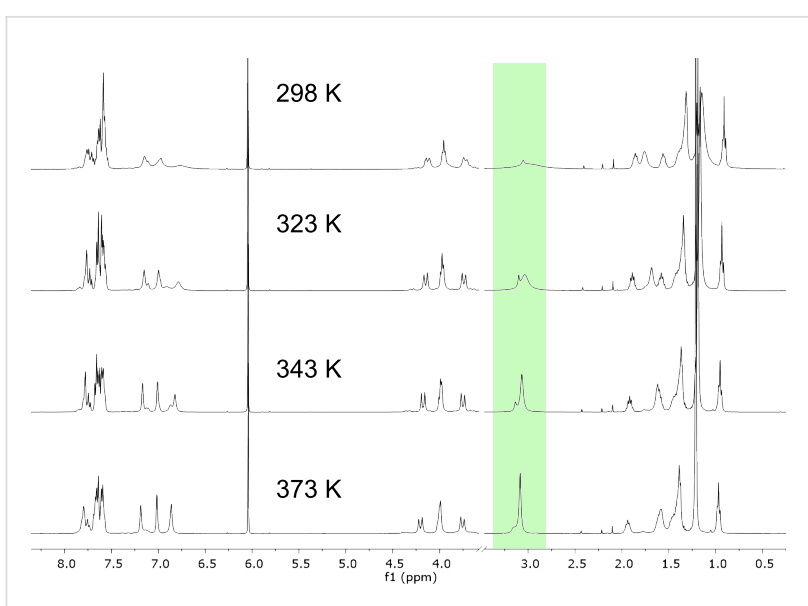

Figure 3: Stacked plot ${ }^{1} \mathrm{H}$ NMR (tetrachloroethane- $\left.d_{2}\right)$ of $\mathbf{A}(\mathrm{AuCl})_{2}$ at variable temperature.

outcomes suggest that the role of the macrocycle for catalysts $\mathbf{A} / \mathbf{B}(\mathrm{AuCl})_{2}$ is not determining in changing the product distribution and that the catalytically active gold(I) nuclei are too far to be influenced by the cavity or by the macrocycle itself.

Finally, the catalytic reaction was attempted using $\mathbf{C}^{\prime}(\mathrm{AuCl})$. We thus observed a selectivity towards product 2a (1.5:1) which might be caused by the different orientation of the phosphine ligand implanted on the aromatic ring (entry 5, Table 1). Interestingly, this effect was substantially improved with the use of the calix[6]arene-based complex $\mathbf{C}(\mathrm{AuCl})_{2}$ (entry 6, Table 1). Overall, the ortho-substituted macrocycle $\mathbf{C}(\mathrm{AuCl})_{2}$ displayed an enhanced selectivity, with respect to the parental macrocycles $\mathbf{A}, \mathbf{B}(\mathrm{AuCl})_{2}$, that arise from the proximity of the two gold(I) nuclei to the calix[6]arene scaffold. Although just

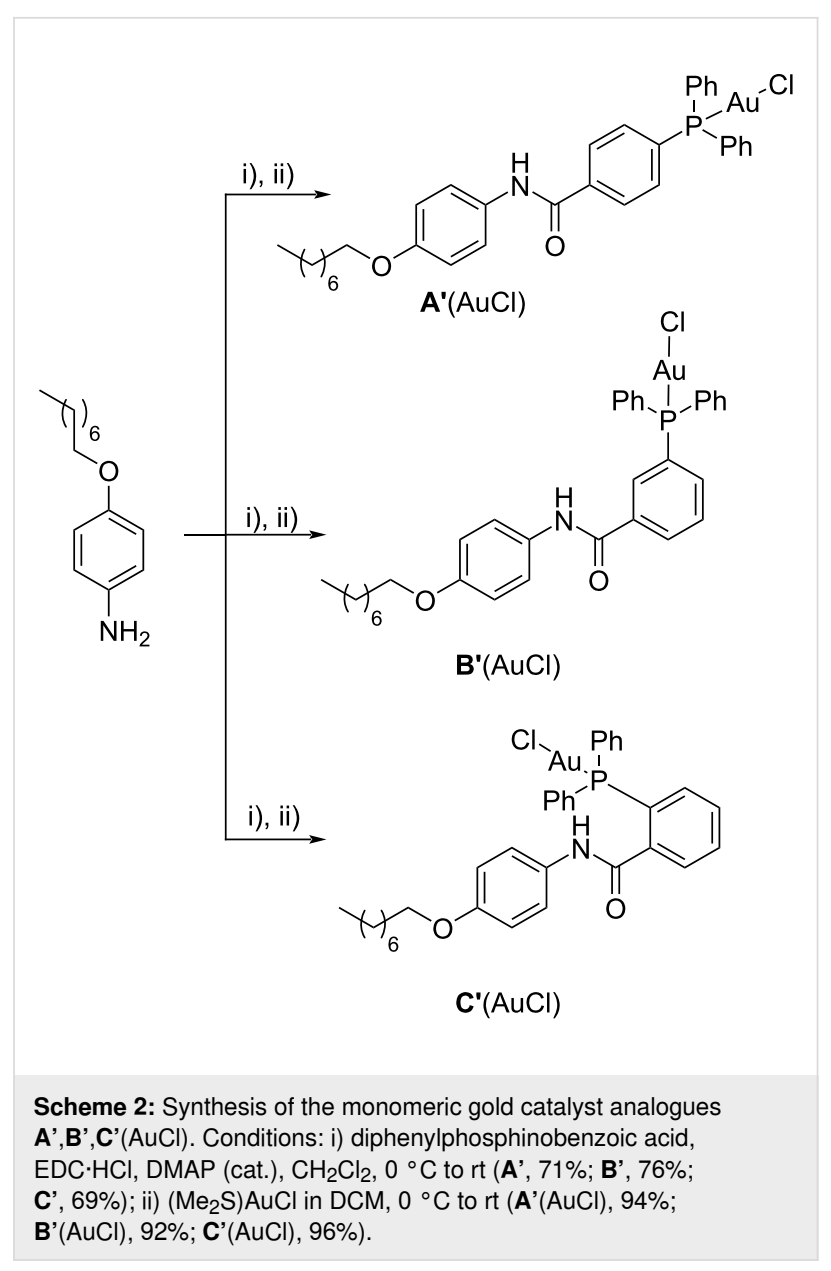

preliminary, these results indicate that the conformational properties of this class of macrocycles can influence the selectivity in gold(I)-catalyzed cycloisomerization of 1,6-enynes.

Table 1: Ligand effect in gold(I)-catalyzed cycloisomerization of $\mathbf{1 a}$.<smiles>C#CCC(C/C=C/c1ccccc1)(COCC)C(OCC)OCC</smiles>

\section{$[\mathrm{Au}] / \mathrm{AgSbF}_{6}$ \\ $\mathrm{CH}_{2} \mathrm{Cl}_{2}, 4 \AA \mathrm{MS}$}

$\mathrm{rt}, 4 \mathrm{~h}$

$$
[\mathrm{Au}]
$$

$\mathbf{A}^{\prime}(\mathrm{AuCl})(2 \mathrm{~mol} \%)$

$\mathbf{A}(\mathrm{AuCl})_{2}(1 \mathrm{~mol} \%)$

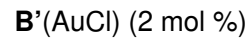

$\mathbf{B}(\mathrm{AuCl})_{2}(1 \mathrm{~mol} \%)$

C'$^{\prime}(\mathrm{AuCl})(2 \mathrm{~mol} \%)$

C $(\mathrm{AuCl})_{2}(1 \mathrm{~mol} \%)$<smiles>CCOCC1(C(=O)OCC)CC=CC(=Cc2ccccc2)C1</smiles>

$2 a$

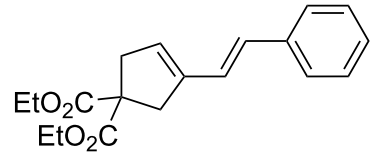

2b

\begin{tabular}{llll}
\hline Entry $^{\mathrm{a}}$ & {$[\mathrm{Au}]$} & conv. [\%] & $\mathbf{2 a / 2 \mathbf { b }}$ \\
\hline 1 & $\mathbf{A}^{\prime}(\mathrm{AuCl})(2 \mathrm{~mol} \%)$ & 89 & $1.0: 1.0$ \\
2 & $\mathbf{A}(\mathrm{AuCl})_{2}(1 \mathrm{~mol} \%)$ & 88 & $1.1: 1.0$ \\
3 & $\mathbf{B}^{\prime}(\mathrm{AuCl})(2 \mathrm{~mol} \%)$ & 86 & $1.2: 1.0$ \\
4 & $\mathbf{B}(\mathrm{AuCl})_{2}(1 \mathrm{~mol} \%)$ & 91 & $1.1: 1.0$ \\
5 & $\mathbf{C}^{\prime}(\mathrm{AuCl})(2 \mathrm{~mol} \%)$ & 86 & $1.5: 1.0$ \\
6 & $\mathbf{C}(\mathrm{AuCl})_{2}(1 \mathrm{~mol} \%)$ & 89 & $1.8: 1.0$ \\
\hline
\end{tabular}

aReaction conditions: $1 \mathrm{a}(0.2 \mathrm{mmol}), \mathrm{AgSbF}_{6}(2.0 \mathrm{~mol} \%), \mathrm{CH}_{2} \mathrm{Cl}_{2}(0.1 \mathrm{M}), 4 \mathrm{~h}$. 


\section{Conclusion}

We reported the synthesis of a novel family of diametric diphosphine gold(I) complexes whose geometry in low-polarity solvents is controlled by the 1,2,3-alternate conformation of the calix[6]arene precursor. These catalysts are able to tune the selectivity of catalytic cycloisomerization of 1,6-enynes as a function of the relative orientation of the bonded gold(I) nuclei with respect to the macrocycle. Further studies are currently under progress to outline the role of the macrocycle and to verify if a possible re-orientation of the gold(I) nuclei towards the center of the aromatic cavity can play any role in dictating the selectivity of the catalytic transformation.

\section{Experimental}

General procedure for catalysis: In a $10 \mathrm{~mL}$ two-necked roundbottomed flask containing $\mathbf{A}(\mathrm{AuCl})_{2}(1.0 \mathrm{~mol} \%, 4.4 \mathrm{mg})$ or A'(AuCl) $(2.0 \mathrm{~mol} \%, 3.0 \mathrm{mg})$, dry $\mathrm{CH}_{2} \mathrm{Cl}_{2}(2.0 \mathrm{~mL})$ was added under nitrogen atmosphere. Subsequently, a tip of spatula (micro spatula, Heyman type $16 \mathrm{~cm}$ ) of $\mathrm{AgSbF}_{6}(\approx 2.0 \mathrm{~mol} \%$, $\approx 2 \mathrm{mg}$ ) was added along with $20 \mathrm{mg}$ of $4 \AA$ molecular sieves. The flask was covered with an aluminum foil and the mixture stirred for 5 minutes. Subsequently, 1a $(0.2 \mathrm{mmol}, 63.0 \mathrm{mg})$ was added and the reaction mixture was stirred for 4 hours After completion, the mixture was diluted with $20 \mathrm{~mL}$ of $\mathrm{CH}_{2} \mathrm{Cl}_{2}$, filtered through a pad of celite, and transferred in a $100 \mathrm{~mL}$ flask where it was concentrated under reduced atmosphere. Conversions and selectivities were determined by ${ }^{1} \mathrm{H}$ NMR analysis (data confirmed by performing the reaction twice). ${ }^{1} \mathrm{H}$ NMR (2a) $\left(400 \mathrm{MHz}, \mathrm{CDCl}_{3}\right) \delta 7.48-7.19$ (m, $5 \mathrm{H}), 6.63(\mathrm{dtd}, J=10.1,2.1,1.0 \mathrm{~Hz}, 1 \mathrm{H}), 6.37$ (s, 1H), 5.90 $(\mathrm{dtd}, J=10.1,4.0,1.6 \mathrm{~Hz}, 1 \mathrm{H}), 4.30-4.21(\mathrm{~m}, 4 \mathrm{H}), 2.98(\mathrm{~d}$, $J=1.6 \mathrm{~Hz}, 2 \mathrm{H}), 2.78(\mathrm{ddd}, J=4.0,2.1,0.9 \mathrm{~Hz}, 2 \mathrm{H}), 1.32-1.24$ $(\mathrm{m}, 6 \mathrm{H}) .{ }^{1} \mathrm{H}$ NMR $(\mathbf{2 b})\left(400 \mathrm{MHz}, \mathrm{CDCl}_{3}\right) \delta 7.48-7.20(\mathrm{~m}$ $5 \mathrm{H}), 6.93(\mathrm{~d}, J=16.2 \mathrm{~Hz}, 1 \mathrm{H}), 6.48(\mathrm{~d}, J=16.2 \mathrm{~Hz}, 1 \mathrm{H}), 5.73$ (ddd, $J=2.7,1.9,0.9 \mathrm{~Hz}, 1 \mathrm{H}), 4.23-4.14(\mathrm{~m}, 4 \mathrm{H}), 3.28(\mathrm{dd}, J=$ $1.9,0.9 \mathrm{~Hz}, 2 \mathrm{H}), 3.18(\mathrm{dd}, J=1.9,0.9 \mathrm{~Hz}, 2 \mathrm{H}), 1.32-1.21(\mathrm{~m}$, $6 \mathrm{H})$.

\section{Supporting Information}

\section{Supporting Information File 1}

Experimental procedures, characterization data of compounds and copies of NMR spectra.

[https://www.beilstein-journals.org/bjoc/content/ supplementary/1860-5397-18-21-S1.pdf]

\section{Acknowledgements}

The authors thank Centro Interdipartimentale di Misure of the University of Parma for NMR measurements.

\section{Funding}

This work was supported by the Italian MIUR (PRIN 20173L7W8 K). This work was carried out within the COMPHUB Initiative, funded by the "Departments of Excellence" program of the Italian Ministry of Education, University and Research (MIUR, 2018-2020).

\section{ORCID ${ }^{\circledR}$ iDs}

Andrea Secchi - https://orcid.org/0000-0003-4045-961X Gianpiero Cera - https://orcid.org/0000-0002-2702-282X

\section{References}

1. Kaya, Z.; Bentouhami, E.; Pelzer, K.; Armspach, D. Coord. Chem. Rev. 2021, 445, 214066. doi:10.1016/j.ccr.2021.214066

2. Olivo, G.; Capocasa, G.; Del Giudice, D.; Lanzalunga, O.; Di Stefano, S. Chem. Soc. Rev. 2021, 50, 7681-7724. doi:10.1039/d1cs00175b

3. Gramage-Doria, R.; Armspach, D.; Matt, D. Coord. Chem. Rev. 2013, 257, 776-816. doi:10.1016/j.ccr.2012.10.006

4. Kamer, P. C. J.; van Leeuwen, P. W. N. M., Eds. Phosphorus(III) Ligands in Homogeneous Catalysis: Design and Synthesis; John Wiley \& Sons: Chichester, UK, 2012. doi:10.1002/9781118299715

5. Orton, G. R. F.; Pilgrim, B. S.; Champness, N. R. Chem. Soc. Rev. 2021, 50, 4411-4431. doi:10.1039/d0cs01556c

6. Shet, H.; Parmar, U.; Bhilare, S.; Kapdi, A. R. Org. Chem. Front. 2021, 8, 1599-1656. doi:10.1039/d0qo01194k

7. Matt, D.; Harrowfield, J. ChemCatChem 2021, 13, 153-168. doi:10.1002/cctc.202001242

8. Sémeril, D.; Matt, D. Coord. Chem. Rev. 2014, 279, 58-95. doi:10.1016/j.ccr.2014.06.019

9. Schöttle, C.; Guan, E.; Okrut, A.; Grosso-Giordano, N. A.; Palermo, A.; Solovyov, A.; Gates, B. C.; Katz, A. J. Am. Chem. Soc. 2019, 141, 4010-4015. doi:10.1021/jacs.8b13013

10. Karpus, A.; Yesypenko, O.; Boiko, V.; Poli, R.; Daran, J.-C.; Voitenko, Z.; Kalchenko, V.; Manoury, E. Eur. J. Org. Chem. 2016, 3386-3394. doi:10.1002/ejoc.201600208

11. Elaieb, F.; Hedhli, A.; Sémeril, D.; Matt, D. Eur. J. Org. Chem. 2016 1867-1873. doi:10.1002/ejoc.201600055

12. Monnereau, L.; Sémeril, D.; Matt, D.; Toupet, L. Adv. Synth. Catal. 2009, 351, 1629-1636. doi:10.1002/adsc.200900074

13. Sémeril, D.; Matt, D.; Toupet, L. Chem. - Eur. J. 2008, 14, 7144-7155. doi:10.1002/chem.200800747

14. Chavagnan, T.; Sémeril, D.; Matt, D.; Toupet, L. Eur. J. Org. Chem. 2017, 313-323. doi:10.1002/ejoc.201601278

15. Chavagnan, T.; Sémeril, D.; Matt, D.; Harrowfield, J.; Toupet, L. Chem. - Eur. J. 2015, 21, 6678-6681. doi:10.1002/chem.201500177

16. El Moll, H.; Sémeril, D.; Matt, D.; Toupet, L. Adv. Synth. Catal. 2010, 352, 901-908. doi:10.1002/adsc.200900767

17. El Moll, H.; Sémeril, D.; Matt, D.; Youinou, M.-T.; Toupet, L. Org. Biomol. Chem. 2009, 7, 495-501. doi:10.1039/b813373e

18. Martín-Torres, I.; Ogalla, G.; Yang, J.-M.; Rinaldi, A.; Echavarren, A. M. Angew. Chem., Int. Ed. 2021, 60, 9339-9344. doi:10.1002/anie.202017035

19. Rusali, L. E.; Schramm, M. P. Tetrahedron Lett. 2020, 61, 152333. doi:10.1016/j.tetlet.2020.152333 
20. Inoue, M.; Kamiguchi, S.; Ugawa, K.; Hkiri, S.; Bouffard, J.; Sémeril, D.; Iwasawa, T. Eur. J. Org. Chem. 2019, 6261-6268. doi:10.1002/ejoc.201901058

21. Ho, T. D.; Schramm, M. P. Eur. J. Org. Chem. 2019, 5678-5684. doi:10.1002/ejoc.201900829

22. Inoue, M.; Ugawa, K.; Maruyama, T.; Iwasawa, T. Eur. J. Org. Chem. 2018, 5304-5311. doi:10.1002/ejoc.201800948

23. Endo, N.; Inoue, M.; Iwasawa, T. Eur. J. Org. Chem. 2018, 1136-1140. doi:10.1002/ejoc.201701613

24. Schramm, M. P.; Kanaura, M.; Ito, K.; Ide, M.; Iwasawa, T. Eur. J. Org. Chem. 2016, 813-820. doi:10.1002/ejoc.201501426

25. Endo, N.; Kanaura, M.; Schramm, M. P.; Iwasawa, T. Eur. J. Org. Chem. 2016, 2514-2521. doi:10.1002/ejoc.201600362

26. Mitschke, B.; Turberg, M.; List, B. Chem 2020, 6, 2515-2532. doi:10.1016/j.chempr.2020.09.007

27. Mouarrawis, V.; Plessius, R.; van der Vlugt, J. I.; Reek, J. N. H. Front. Chem. (Lausanne, Switz.) 2018, 6, 623. doi:10.3389/fchem.2018.00623

28. Homden, D. M.; Redshaw, C. Chem. Rev. 2008, 108, 5086-5130. doi:10.1021/cr8002196

29. Cera, G.; Arduini, A.; Secchi, A.; Credi, A.; Silvi, S. Chem. Rec. 2021, 21, 1161-1181. doi:10.1002/tcr.202100012

30. Cera, G.; Giovanardi, G.; Secchi, A.; Arduini, A. Chem. - Eur. J. 2021, 27, 10261-10266. doi:10.1002/chem.202101323

31. Cera, G.; Cester Bonati, F.; Bazzoni, M.; Secchi, A.; Arduini, A. Org. Biomol. Chem. 2021, 19, 1546-1554. doi:10.1039/d0ob02393k

32. Cera, G.; Bazzoni, M.; Arduini, A.; Secchi, A. Org. Lett. 2020, 22, 3702-3705. doi:10.1021/acs.orglett.0c01191

33. Bazzoni, M.; Zanichelli, V.; Casimiro, L.; Massera, C.; Credi, A.; Secchi, A.; Silvi, S.; Arduini, A. Eur. J. Org. Chem. 2019, 3513-3524. doi:10.1002/ejoc.201900211

34. Cera, G.; Bazzoni, M.; Andreoni, L.; Cester Bonati, F.; Massera, C. Silvi, S.; Credi, A.; Secchi, A.; Arduini, A. Eur. J. Org. Chem. 2021, 5788-5798. doi:10.1002/ejoc.202101080

35. van Duynhoven, J. P. M.; Janssen, R. G.; Verboom, W.; Franken, S. M.; Casnati, A.; Pochini, A.; Ungaro, R.; de Mendoza, J.; Nieto, P. M. J. Am. Chem. Soc. 1994, 116, 5814-5822. doi:10.1021/ja00092a036

36. Nieto-Oberhuber, C.; Paz Muñoz, M.; López, S.; Jiménez-Núñez, E.; Nevado, C.; Herrero-Gómez, E.; Raducan, M.; Echavarren, A. M. Chem. - Eur. J. 2006, 12, 1677-1693. doi:10.1002/chem.200501088

37. A model reaction performed with $\mathrm{AgSbF}_{6}(2 \mathrm{~mol} \%)$ as the catalyst, in the absence of any gold(I) complex, did not lead to any conversion of starting material 1a.

38. Fürstner, A.; Morency, L. Angew. Chem., Int. Ed. 2008, 47, 5030-5033. doi:10.1002/anie.200800934

39. Jiménez-Núñez, E.; Echavarren, A. M. Chem. Rev. 2008, 108, 3326-3350. doi:10.1021/cr0684319

\section{License and Terms}

This is an open access article licensed under the terms of the Beilstein-Institut Open Access License Agreement (https://www.beilstein-journals.org/bjoc/terms), which is identical to the Creative Commons Attribution 4.0 International License

(https://creativecommons.org/licenses/by/4.0). The reuse of material under this license requires that the author(s), source and license are credited. Third-party material in this article could be subject to other licenses (typically indicated in the credit line), and in this case, users are required to obtain permission from the license holder to reuse the material.

The definitive version of this article is the electronic one which can be found at: https://doi.org/10.3762/bjoc.18.21 